\title{
High risky behavior and HIV/AIDS knowledge amongst street children in Shiraz, Iran
}

\author{
Nasrin Motazedian*1 (1), Mehrab Sayadi ${ }^{2}$, Shohreh Beheshti ${ }^{3}$, Nooshin $^{2}$ arei ${ }^{3}$, Javad Ghaderi ${ }^{4}$ \\ Received: 10 Nov 2018 \\ Published: 15 Oct 2020
}

\begin{abstract}
Background: Street children around the world are accompanying a wide range of risky behaviors. The most common ones include risky sexual behavior, substance and alcohol abuse, and violence. This study aimed to assess risk behaviors and HIV knowledge of street children in Shiraz.

Methods: A total of 329 street children (7-18 years of age who spend days or nights on streets with or without their family for earning money) were interviewed through 2014-2016 in Shiraz. Data were collected through a structured interview about high-risk behaviors and HIV/AIDS Knowledge based on a form and questionnaire. Street children were asked to identify HIV/AIDS mode of transmission. All correct answers were scored as one (1), and incorrect, "don't know" responses and no responses scored as zero. The data were analyzed by SPSS software 16 (SPSS, Inc. Chicago, USA) using the Independent t-test and chi-square test, and Pearson's correlation test. $\mathrm{P}$ value $<0.05$ was considered as statistically significant

Results: The mean \pm SD age was $13.46 \pm 3.09$. A total of $86.6 \%$ of them were boys. A total of $97.6 \%$ of them reported staying with their parents. Street children reported sleeping place as follow: with their parents $(n=312,94.8 \%)$, sharing accommodation with other kids $(n=13, \% 4)$, sleeping in parks $(n=2,7 \%)$, and one with relatives. The frequency of smoking, alcohol drinking, and drug abuse were $35(10.6 \%), 47(14.3 \%)$, and $6(1.8 \%)$ respectively. A total of $43(13.1 \%)$ street children reported sexual activity, among them $30(9.1 \%)$ had sexual activity without a condom. Mean \pm SD HIV/AIDS knowledge scoring of street children was, 4.1 \pm 3.9 .

Conclusion: Special programs should be implemented in order to reduce high-risk behavior among street children. Intervention should include increasing awareness about alcohol and drug abuse, HIV/AIDS knowledge, sexual and verbal abuse through an organized system with the help of peer education.
\end{abstract}

Keywords: Children, Street, Behaviors, Risk, Knowledge, HIV/AIDS

Conflicts of Interest: None declared

Funding: None

*This work has been published under CC BY-NC-SA 1.0 license.

Copyright $\odot$ Iran University of Medical Sciences

Cite this article as: Motazedian N, Sayadi M, Beheshti Sh, Zarei N, Ghaderi J. High risky behavior and HIV/AIDS knowledge amongst street children in Shiraz, Iran. Med J Islam Repub Iran. 2020 (15 Oct);34:138. https://doi.org/10.47176/mjiri.34.138

\section{Introduction}

UNCHS has defined street children as "any girl or boy for whom the street has become his or her habitual abode and or source of livelihood; and who is inadequately protected, supervised, or directed by responsible adults" (1).

Corresponding author: Dr Nasrin Motazedian, motazediann@yahoo.com nmotazedi@sums.ac.ir

1. Shiraz Transplant Research Center, Shiraz University of Medical Sciences, Shiraz, Iran 2. Cardiovascular Research Center, Shiraz University of Medical Sciences, Shiraz, Iran

3. Shiraz HIV/AIDS Research Center, Shiraz University of Medical Science, Shiraz, Iran

4. Faculty of Educational Sciences and Psychology, Payame Noor University, Eqlid, Iran
Clearly, street children around the world are conducting a wide range of risky behaviors. The most common ones include risky sexual behavior, substance and alcohol abuse, and violence (2-5). Heavy manual labor, transportation and

$\uparrow$ What is "already known" in this topic:

Street children are exposed to a wide range of risky behaviors. The most common ones include risky sexual behavior, substance and alcohol abuse and violence.

\section{$\rightarrow$ What this article adds:}

The most of street children in this study were not homeless, but there is a report of smoking, alcohol drinking, and drug abuse among them. These findings emphasize on the implementation of educational and preventive programs for children and their families. 
sale of illegal alcohol and narcotics, robbery, pick-pocketing, and commercial sex work are some forms of the risky occupational behavior that they are faced with.

Consuming narcotic drugs can often increase risky sexual behavior, including commercial sex work, exchanging sex for drugs, and forced sex. These high-risk behaviors could lead to being exposed to HIV, other sexually transmitted infections and violence (6). Age over 13, imprisonment, disgust toward the public, prostitution in exchange for food, shelter, drug supply, and poverty were linked with substance abuse (7). The most important factors with street children phenomenon are being boy, unemployed, low-education level, addicted and divorced parents, and parents with a history of incarceration $(7,8)$. Such risk factors reinforce the risk of spreading HIV and STDs among street children in Iran. According to a study in the city of Tehran, Iran, the overall HIV prevalence was $1.7 \%$. Factors associated with HIV infection included history of drug abuse, place of birth, older age, and unemployment (9).

According to the result of a systematic review in Iran, most of the street children come from crowded and lowincome families and are either rural-urban migrants or from Afghanistan. Most of their parents had a low-education level, and their fathers were unemployed or had lowincome jobs (10).

Despite a low prevalence of smoking and substance abuse, the findings of another study confirmed that more than one-third of street children had experienced smoking throughout their lifetime (7). No reports for HIV have been shown. Nevertheless, about one percent of HCV Ab prevalence have been reported. About $34.5 \%$ of girls and $4.4 \%$ of boys were engaged in sexual activity (11).

Reviewing previous studies about HIV knowledge of street children shows a wide range of knowledge $(12,13)$.

On the one hand, this group is vulnerable due to the very young age; on the other hand, coping and modification are easier at an early age if social organizations support it. So, this study aimed to assess the prevalence of risk behaviors and HIV knowledge of street children in Shiraz.

\section{Methods}

This cross-sectional study was conducted in Shiraz 20142016. According to Shiraz municipality districts, Shiraz is divided into 11 districts. We selected 6 districts that were prone to street children's workplace and accessible for interviewers. A total of 329 street children were interviewed, 50 of them were interviewed in the Social Harms Impact Management Organizations (SHIMO). The others were interviewed in the streets. In order to increase their willingness to participate, the interviewers approached the street kids by purchasing something from them, for example, buying gum, hair clips, socks, and etc. Street children in this study were children 7-18 years of age who spend days or nights on streets with or without their family for earning money. Those children who were not willing to cooperate were excluded from the study. Data were collected through a structured interview based on a form and HIV/AIDS knowledge questionnaire. The reliability and validity of the questionnaire have been checked in a previous study (14). The parts of the data collecting form were as follow socio- demographic variables, information about high-risk behavior in children and their parents. Street children were asked to identify HIV/AIDS mode of transmission. All correct answers were scored as one (1), and incorrect, "don't know" responses and no responses scored as zero. After the summation of 12 items, we had a range of 0 up to 12 scores for any person.

Open-ended questions were coded by the interviewers. The data were analyzed by SPSS software 16 (SPSS, Inc. Chicago, USA) using Independent samples t-test and chisquare test, and Pearson's correlation test. P-value $<0.05$ was considered as statistically significant.

Ethical Considerations: Firstly, before the implementation of the study, we informed the Governor of Fars province, and in the second step, we introduced our project to the welfare organization as the main guardian of street children. This study was conducted under the supervision of Governor of Fars province, and the Welfare Organization for the implementation of the study. Finally, our study was approved by the local Ethics Committee of Shiraz University of Medical Sciences. Five local psychologists were trained on how to fill the form. At first, the interviewers explained the objectives of the study, then the children were assured of confidentiality and informed about the right to withdraw from the study at any time during the interview and were free to decide whether to participate in the research, then they gave verbal consent for participation. Each interview lasted 30 minutes and was conducted privately and anonymously.

\section{Results}

In this study, 329 street children with a mean \pm SD age of $(13.46 \pm 3.09)$ were interviewed. A total of $285(86.6 \%)$ of them were boys. The number of children who were living in a family ranged from 2-14 with mean $\pm \mathrm{SD}(6 \pm 2)$. Working hours in a day were 1-16 hours with mean \pm SD (6.58 \pm 2.51$)$. A total of 131 (39.8\%) were studying in the elementary level (Table 1). Length of being on the street was one week to 132 months. A total of $321(97.6 \%)$ of them reported staying with their parents. Street children reported sleeping place as follow: with their parents 312 (94.8\%), sharing accommodation with other kids 13 (4\%), sleeping in parks $2(7 \%)$, and one with relatives. A total of $279(84.8 \%), 263(79.9 \%)$ of them reported having financial and emotional support from their family. The frequency of smoking, alcohol drinking, and drug abuse were $35(10.6 \%), 47(14.3 \%), 6(1.8 \%)$ respectively. A total of $43(13.1 \%)$ of street children reported sexual activity; among them, $30(9.1 \%)$ had sexual activity without a condom.

Positive history of smoking in the family in $171(52.0 \%)$, and drug abuse in $71(21.6 \%)$ cases were detected. No drug injection reported amongst street children. A total of $48(14.6 \%)$ reported various types of violence (Table 2 ).

At least having one risk behavior such as: smoking, drinking alcohol, drug abuse, sexual activity defined as risk behavior among street children. There were significant relationships between age, gender, education, risky behaviors in the family and risk behavior among street children in Shiraz (Table 3). 


\begin{tabular}{|c|c|c|c|c|}
\hline \multirow[t]{2}{*}{ Variables } & \multirow[t]{2}{*}{ Total } & \multicolumn{2}{|c|}{ Region } & \multirow[t]{2}{*}{$\bar{p}$} \\
\hline & & Social organization $(n=50)$ & Street $(n=279)$ & \\
\hline Age & $13.46 \pm 3.09$ & $11.1 \pm 2.4$ & $13.8 \pm 3.0$ & $<0.001$ \\
\hline Gender & & & & 0.034 \\
\hline Male & $285(86.6)$ & $48(96.0)$ & $237(84.9)$ & \\
\hline Female & $44(13.4)$ & $2(4.0)$ & $42(15.1)$ & \\
\hline Birthplace & & & & 0.007 \\
\hline Urban & $287(87.2)$ & $46(100)$ & $241(88.3)$ & \\
\hline Rural & $32(9.7)$ & $0(0)$ & $32(11.7)$ & \\
\hline Unknown & $10(3)$ & 4 & 6 & \\
\hline Nationality & & & & $<0.001$ \\
\hline Iranian & $167(50.8)$ & $4(8.3)$ & $163(59.7)$ & \\
\hline Non-Iranian & $161(49.2)$ & $44(91.7)$ & $110(40.3)$ & \\
\hline Education & & & & $<0.001$ \\
\hline Illiterate & $18(5.5)$ & $10(20.0)$ & $8(2.9)$ & \\
\hline Elementary & $131(39.8)$ & $35(70.0)$ & $96(34.4)$ & \\
\hline Guidance & $97(29.5)$ & $5(10.0)$ & $92(33.0)$ & \\
\hline High school & $70(21.3)$ & 0 & $70(25.1)$ & \\
\hline Diploma & $13(4)$ & 0 & $13(4.7)$ & \\
\hline Present education status & & & & 0.219 \\
\hline Studying & $242(73.6)$ & $32(68.1)$ & $210(77.8)$ & \\
\hline Dropout & $71(21.6)$ & $15(31.9)$ & $56(20.7)$ & \\
\hline Lagging school year & $16(4.8)$ & 0 & $4(1.5)$ & \\
\hline
\end{tabular}

Table 2. Risk behavior among street children and their parents in Shiraz, 2014-2016

\begin{tabular}{|c|c|c|c|c|}
\hline \multirow[t]{2}{*}{ Risk behavior } & \multirow[b]{2}{*}{$\begin{array}{l}\text { Total } \\
\text { N (\%) }\end{array}$} & \multicolumn{2}{|c|}{ Region } & \multirow[t]{2}{*}{$\mathrm{p}$} \\
\hline & & $\begin{array}{c}\text { Organization } \\
\mathrm{N}(\%)\end{array}$ & $\begin{array}{l}\text { Street } \\
N(\%)\end{array}$ & \\
\hline \multicolumn{5}{|l|}{ Family } \\
\hline At least one risk & $199(60.5)$ & $27(54.0)$ & $172(61.6)$ & 0.308 \\
\hline Smoking & $171(52.0)$ & $15(30.0)$ & $156(55.9)$ & 0.001 \\
\hline Drinking alcohol & $26(7.9)$ & $2(4.0)$ & $24(8.6)$ & 0.267 \\
\hline Drug abuse & $71(21.6)$ & $13(26.0)$ & $58(20.8)$ & 0.409 \\
\hline Injection Drug & $5(1.5)$ & $1(2.0)$ & $4(1.4)$ & 0.763 \\
\hline Prison & $50(15.2)$ & $12(24.0)$ & $38(13.6)$ & 0.060 \\
\hline \multicolumn{5}{|l|}{ Street children } \\
\hline At least one risk & $75(22.8)$ & $3(6.0)$ & $72(25.8)$ & 0.002 \\
\hline Smoking & $35(10.6)$ & $1(2.0)$ & $34(12.2)$ & 0.031 \\
\hline Drinking alcohol & $47(14.3)$ & 0 & $47(16.8)$ & $<0.001$ \\
\hline Drug abuse & $6(1.8)$ & 0 & $6(2.2)$ & 0.596 \\
\hline Sexual activity & $43(13.1)$ & $2(4.0)$ & $41(14.7)$ & 0.038 \\
\hline Sexual activity without condom & $30(9.1)$ & 0 & $30(18.8)$ & 0.016 \\
\hline Sexual activity with condom & $34(10.3)$ & $1(4.3)$ & $33(21.2)$ & 0.083 \\
\hline Homosexually & $14(4.3)$ & 0 & $14(9.1)$ & 0.221 \\
\hline Various type of violence & $48(14.6)$ & $10(20.0)$ & $38(13.8)$ & 0.278 \\
\hline Physical violence & $40(12.2)$ & $5(10.0)$ & $35(12.5)$ & 0.612 \\
\hline Mental and emotional violence & $26(7.9)$ & $9(18.0)$ & $17(6.1)$ & 0.009 \\
\hline Sexual violence & $12(3.6)$ & 0 & $12(4.3)$ & 0.225 \\
\hline Beggary & $33(10)$ & $23(46.0)$ & $10(3.6)$ & $<0.001$ \\
\hline Theft & $4(1.2)$ & $2(4.0)$ & $2(0.7)$ & 0.001 \\
\hline Running away from home & $10(3.0)$ & 0 & $10(3.6)$ & 0.370 \\
\hline Prison & $3(0.9)$ & 0 & $3(1.1)$ & 0.461 \\
\hline
\end{tabular}

A total of $152(46.2 \%)$ of street children did not have any knowledge of HIV (had zero scores out of 12) and mean \pm SD of knowledge score was $4.1 \pm 3.9$ (out of 12). Crude response to HIV/AIDS's mode of transmission questions summarized in Table 4.
There was a significant correlation between HIV knowledge and their age $(\mathrm{r}=0.692, \mathrm{p}<0.001)$. HIV/AIDS knowledge of street children according to their demographic characteristics and their risky behavior summarized in Table 5. Results showed that their HIV knowledge was

Table 3. Factors associated with risk behavior among street children in Shiraz, 2014-2016

\begin{tabular}{|c|c|c|c|c|}
\hline \multirow{2}{*}{\multicolumn{2}{|c|}{ Variable }} & \multicolumn{2}{|c|}{ Having Risky behavior } & \multirow[t]{2}{*}{$\mathrm{p}$} \\
\hline & & Yes $(n=75)$ & No $(n=254)$ & \\
\hline Age & & $16.55 \pm 1.34$ & $12.55 \pm 2.86$ & $<0.001$ \\
\hline Gender $(\mathrm{M}$ & & $72(96.0)$ & $213(83.9)$ & 0.007 \\
\hline \multirow{3}{*}{ Education } & Illiterate \& Elementary & $11(14.7)$ & $138(54.3)$ & $<0.001$ \\
\hline & Guidance & $20(26.7)$ & $77(30.3)$ & \\
\hline & High school \&Diploma & $44(58.7)$ & $39(15.4)$ & \\
\hline \multicolumn{2}{|c|}{ Risky behaviors in the family } & $56(74.7)$ & $143(56.3)$ & 0.004 \\
\hline
\end{tabular}




\begin{tabular}{|c|c|c|c|c|}
\hline Variables & Yes & No & Don't know & No response \\
\hline Have you heard about HIV & $171(52)$ & $117(35.6)$ & $40(12.2)$ & $1(0.3)$ \\
\hline HIV transmitted through insect bite & $53(16.1)$ & $83(25.2)$ & $182(55.3)$ & $11(3.3)$ \\
\hline HIV transmitted through kissing & $56(17)$ & $89(27.1)$ & 174(52.9) & $10(3)$ \\
\hline HIV transmitted through tattoo & $86(26.1)$ & $36(10.9)$ & 197(59.9) & $10(3)$ \\
\hline HIV transmitted through blood transfusion & $138(41.9)$ & $6(1.8)$ & $175(53.2)$ & 10(3) \\
\hline HIV transmitted through injecting drugs & $139(42.2)$ & $11(r, \pi)$ & $169(51.4)$ & 10(3) \\
\hline HIV transmitted through sharing a needle & $151(45.9)$ & $5(1.5)$ & $163(49.5)$ & $10(3)$ \\
\hline HIV transmitted through breastfeeding & 63(19.1) & $74(22.5)$ & $182(55.3)$ & $10(3)$ \\
\hline $\begin{array}{l}\text { HIV transmitted through pregnant women to } \\
\text { child }\end{array}$ & $72(21.9)$ & $53(16.1)$ & 193(58.7) & $11(3.3)$ \\
\hline HIV transmitted through sex & $135(41)$ & $13(4)$ & $170(51.67)$ & $11(3.3)$ \\
\hline HIV transmitted through oral sex & $74(22.5)$ & $37(11.2)$ & $206(62.6)$ & 11(3.6) \\
\hline HIV transmitted through anal sex & $93(28.3)$ & $19(5.8)$ & $205(62.3)$ & 11(3.6) \\
\hline Variables & & & Mean \pm SD & $\mathrm{p}$ \\
\hline Age (yr.) & & & & $<0.001$ \\
\hline$<=12$ & & & $0.7 \pm 2.1$ & \\
\hline$>12$ & & & $5.9 \pm 3.8$ & \\
\hline Gender & & & & 0.001 \\
\hline Male & & & $4.2 \pm 4.1$ & \\
\hline Female & & & $2.1 \pm 3.7$ & \\
\hline Education & & & & $<0.001$ \\
\hline Irritate \&elementary & & & $1.1 \pm 2.6$ & \\
\hline Guidance & & & $4.7 \pm 4.1$ & \\
\hline High school \& diploma & & & $7.9 \pm 2.5$ & \\
\hline Having at least one risk behavior in family & & & & 0.195 \\
\hline No & & & $3.5 \pm 4.0$ & \\
\hline Yes & & & $4.1 \pm 4.2$ & \\
\hline Having at least one risk behavior & & & & $<0.001$ \\
\hline No & & & $2.85 \pm 3.8$ & \\
\hline Yes & & & $7.5 \pm 2.9$ & \\
\hline Smoking & & & & $<0.001$ \\
\hline No & & & $3.4 \pm 4.1$ & \\
\hline Yes & & & $7.8 \pm 1.8$ & \\
\hline Alcohol drinking & & & & $<0.001$ \\
\hline No & & & $3.2 \pm 3.9$ & \\
\hline Yes & & & $8.1 \pm 2.7$ & \\
\hline Drug abuse & & & & 0.117 \\
\hline No & & & $3.9 \pm 4.1$ & \\
\hline Yes & & & $6.6 \pm 3.5$ & \\
\hline Having Sexual activity & & & & $<0.001$ \\
\hline No & & & $3.3 \pm 4$ & \\
\hline Yes & & & $7.5 \pm 3.2$ & \\
\hline
\end{tabular}

significantly different among age groups, gender and education level. Also there was a significant difference in knowledge level related to their risky behavior

\section{Discussion}

The present study evaluated risky behavior and HIV knowledge awareness amongst street children in Shiraz. The prevalence of smoking, alcohol, and drug abuse was estimated at $10.6 \%, 14.3 \%$, and $1.8 \%$, respectively.

A study conducted on 10-19 years old street children in Tehran showed that $36.7 \%$ of the children had smoked throughout their life, $7.8 \%$ alcohol and $3.6 \%$ narcotic drugs (7). The prevalence of smoking and history of alcohol abuse among male street children in the southeast of Iran (Zahedan) was $42.6 \%$ and $2 \%$, respectively (15). A recent study among working and street children in Tehran reported that $30 \%$ of participants had sexual contact (16). These results were different from ours.

A study from Isfahan on 386 street children showed that majority of them had no history of smoking $(91.7 \%)$, alcohol $(94.8 \%)$ or substance abuse $(97.2 \%)(11)$, which is compatible with our findings.
A systematic review designed in order to investigate street children challenges in Iran. Cigarette smoking (6.9$50 \%$ ), sexual abuse (49.3\%) reported among street children in Iran. A total of $5.8 \%$ of children have a family member with drug abuse (17). Cigarette smoking of children and a history of drug abuse in family members of our participants is compatible with other reports from Iran.

A study in 27 Brazilian state capital cities showed that tobacco and alcohol consumption was higher than our study (18). A systematic review and meta-analysis study showed a pooled prevalence of $44 \%$ for tobacco and $41 \%$ for alcohol use among street children in resource-constrained settings (6). Although our finding on smoking and alcohol drinking was lower, as we know, smoking and alcohol abuse could be an initiator of other types of substance abuse among street children; hence we should pay special attention to implant preventive strategies.

A study in Gondar town reported that $61.7 \%$ of the participants had sexual intercourse experience during their childhood (19). Experiencing sexual intercourse was reported by $(38.9 \%)$ of street children in Isfahan (11). Approximately half of the street children 13-19 years old had risky sexual 
behavior in Nepal (20). These results were higher than our findings.

The prevalence of violence was $14.6 \%$ either physically, sexually, or mentally among our participants . The prevalence of violence or abuse on the street children of Greater Cairo and Alexandria was 93\% (21), which was higher than our findings.

Street children in Zahedan had reported family conflict including violence (36\%), parental drug abuse (33\%), physical abuse (33\%) and abandonment $(32.1 \%)$ ) as their reason for becoming a street child (22).

Present alcohol consumption was in relation to age and sex in Greater Cairo and Alexandria (21). In our study there was a significant relationship between street children risky behavior and their demographic characteristics.

A study from Tehran showed that there was a significant relationship between substance abuse among children and their families (7). Smoking among street children had a significant relationship with smoking in their family. Family circumstances and biological vulnerability could explain this issue.

Our study showed that almost half of the street children did not hear about HIV/AIDS (Table 4). There was a significant relationship between street children's HIV knowledge and their demographic characteristics (Table 5).

A study from Nepal found out that street teenagers had a good knowledge of HIV/AIDS. The level of knowledge was high among the correspondents who had heard about the disease from an organization of Social Services (20). A qualitative study conducted on (5-12 years old) street children in Dhaka city of Bangladesh, they had poor knowledge about transmission mode of HIV and condom use (23). HIV knowledge level in our study was lower than other studies $(7,10,11,24)$. The variation in result could be attributed to participant's age groups, exposure to mass media program on HIV/AIDS, location of the interview, and place of residence. It seems that children in a rehabilitation center or those supported by health organizations had higher knowledge of HIV/AIDS. There is no education program about HIV/AIDS in Iran, which could be a reason for the low level of knowledge among participants.

A total of $5.5 \%$ of our participants were illiterate and 17 of them did not sleep at their home. Studies from other countries show higher findings $(5,18,25)$. A total of $26.4 \%$ of our participants reported dropping out of school or lagging behind in the academic year. Most of our participants lived with their parents, hence increasing parent's awareness and warning them is the best way to prevent such issues. Since leaving school could be considered as an initiator of high-risky behavior.

The sample of this study consisted of only those children, and youth who agreed to participate in the study voluntarily. Consequently, it is possible that children with high risky behavior did not participate in our study. There are areas with a high prevalence of risky behavior in Shiraz, but the interviewers did not go to these areas due to security reasons. A total of 50 participants were interviewed in SHIMO. The majority of them were refugees from Afghanistan $(91.7 \%), 6 \%$ of them reported high-risk behaviors, which was lower than those who were interviewed on the street. This could be due to the lack of privacy and being exposed. Evaluating risky behaviors through interviews is prone to a number of biases that could affect the reliability and validity of the data.

Thus far, this is the only study on street children to interview a high number of street children in Shiraz. Also, the data collection was given special consideration. The interviews were done by an expert psychologist team. They were received additional training.

The majority of children in our study had stated that their family gave financial and emotional support, but due to the high number of children in their family, it seems that parents couldn't afford the financial aspect sufficiently.

It seems that poverty accounted for becoming a street child in our study; thus, family economic reinforcement interventions to prevent children from working on the street can be beneficial. Legal and social support including the opportunity to study and to have access to health services, should also be considered.

Special programs should be implemented in order to reduce high-risk behaviors among street children. Intervention should include increasing awareness about alcohol and drug abuse, HIV/AIDS knowledge, sexual and verbal abuse through an organized system with the help of peer education.

\section{Conclusion}

Poverty accounted as a risk-factor for becoming a street child in our study; thus, family economic reinforcement interventions to prevent children from working on the street can be beneficial. Legal and social support including the opportunity to study and to have access to health services, should also be considered.

Special programs should be implemented in order to reduce high-risk behaviors among street children. Intervention should include increasing awareness about alcohol and drug abuse, HIV/AIDS knowledge, sexual and verbal abuse through an organized system with the help of peer education.

\section{Acknowledgment}

The authors would like to thank the Research Consultation Center (RCC) of Shiraz University of Medical Sciences for their invaluable assistance in editing this article.

\section{Conflict of Interests}

The authors declare that they have no competing interests.

\section{References}

1. Chowdhury S, Chowdhury AS, Huq KE, Jahan Y, Chowdhury R, Ahmed T, et al. Life Style and Risk Behavior of Street Children in Bangladesh: A Health Perspective. Health. 2017;9(04):577.

2. Towe VL, ul Hasan S, Zafar ST, Sherman SG. Street life and drug risk behaviors associated with exchanging sex among male street children in Lahore, Pakistan. J Adolesc Health. 2009;44(3):222-8.

3. Nada KH, El Daw AS. Violence, abuse, alcohol and drug use, and sexual behaviors in street children of Greater Cairo and Alexandria, Egypt. Aids. 2010;24:S39-S44.

4. Njord L, Merrill RM, Njord R, Lindsay R, Pachano JD. Drug use among street children and non - street children in the Philippines. AsiaPac J Public Health. 2010;22(2):203-11. 
5. Senaratna B, Wijewardana B. Risk behaviour of street children in Colombo. Ceylon Med J. 2012;57(3).

6. Embleton L, Mwangi A, Vreeman R, Ayuku D, Braitstein P. The epidemiology of substance use among street children in resourceconstrained settings: a systematic review and meta-analysis. Addiction. 2013;108(10):1722-33.

7. Ahmadkhaniha HR, Mohammadian M, Naserbakht M, Ghazaiepour F. Street children in Tehran and risk factors for substance abuse. Med J Islam Repub Iran. 2010;24(2):83-7.

8. Olaleye Y, Oladeji D. Single Parenthood Impact on Street Children in Ibadan Metropolis, Nigeria. Afr. Stud. Re. 2010;4(2).

9. Zadeh AOT, SeyedAlinaghi S, Hassanzad FF, Hajizadeh M, Mohamadi $\mathrm{S}$, Emamzadeh-Fard S, et al. Prevalence of HIV infection and the correlates among homeless in Tehran, Iran. Asian Pac J Trop Biomed. 2014;4(1):65-8.

10. Vameghi M, Sajadi H, Rafiey H, Rashidian A. The socioeconomic status of street children in Iran: a systematic review on studies over a recent decade. Child Soc. 2014;28(5):352-65.

11. Ataei B, Nokhodian Z, Babak A, Shoaei P, Mohhammadzadeh M, Sadeghi R. Seroprevalence of Hepatitis C (HCV) and Human Immunodeficiency Virus (HIV) infection among street children in Isfahan, Iran. Tehran Univ Med J. 2010;67(11).

12. Kayembe PK, Mapatano MA, Fatuma AB, Nyandwe JK, Mayala GM, Kokolomami JI, et al. Knowledge of HIV, sexual behaviour and correlates of risky sex among street children in Kinshasa, democratic republic of Congo. East Afr J Public Health. 2008;5.

13. Busza JR, Balakireva OM, Teltschik A, Bondar TV, Sereda YV, Meynell C, et al. Street-based adolescents at high risk of HIV in Ukraine. J Epidemiol Commun Health. 2011;65(12):1166-70.

14. Kazerooni PA, Sayadi M, Motazedian N, Sabet M. Sexual Behaviors, Knowledge and Attitudes of Female Sex Workers' towards HIV/AIDS in Shiraz. J Health Sci Surveill Syst. 2014;2(3):99-106.

15. Ansari H, Moghaddam AA, Mohammadi M, Peyvand M, Gorgij A, Sanavi FS. Health Status and Life Situation of Street Children in Zahedan, Southeast of Iran. Health Scope. 2015;4(4).

16. Foroughi M, Moayedi-Nia S, Shoghli A, Bayanolhagh S, Sedaghat A, Mohajeri M, et al. Prevalence of HIV, HBV and HCV among street and labour children in Tehran, Iran. Sex Transm Infect. 2017;93(6):421-3.

17. Vameghi M, Rafiey H, Sajjadi H, Rashidian A. Disadvantages of being a street child in Iran: a systematic review. Int J Adolesc Youth. 2014;19(4):521-35.

18. Moura YGd, Sanchez ZM, Opaleye ES, Neiva-Silva L, Koller SH, Noto AR. Drug use among street children and adolescents: what helps? Cad Saude Publica. 2012;28(7):1371-80.

19. Tadesse N, Ayele TA, Mengesha ZB, Alene KA. High prevalence of HIV/AIDS risky sexual behaviours among street youth in Gondar town: a community based cross sectional study. BMC Res Notes. 2013;6.

20. Gurung G. Knowledge and attitude on HIV/AIDS and sexual behaviour of street teenagers in Kathmandu Valley. J Nepal Health Res Counc. 2004;2 (2):9-13.

21. Nada KH, Suliman EDA. Violence, abuse, alcohol and drug use, and sexual behaviors in street children of greater Cairo and Alexandria, Egypt. AIDS. 2010;24.

22. Ansari H, Moghaddam AA, Mohammadi M, Arbabisarjou A. Predictors of High-Risk Behaviors Among Street Children in Zahedan, Southeastern Iran. Int J High Risk Behav Addict. 2016;5(4).

23. Uddin MJ, Sarma H, Wahed T, Ali MW, Koehlmoos TP, Nahar Q, et al. Vulnerability of Bangladeshi street-children to HIV/AIDS: a qualitative study. BMC Public Health. 2014;14(1):1151.

24. Mudingayi A, Lutala P, Mupenda B. HIV knowledge and sexual risk behavior among street adolescents in rehabilitation centres in Kinshasa; DRC: gender differences. Pan Afr Med. 2011;10:23.

25. Cumber SN, Tsoka-Gwegweni JM. Characteristics of street children in Cameroon: A cross-sectional study. Afr J Prim Health Care Fam. 2016;8(1). 